\title{
Social Prejudice against Epilepsy, due to Lack of Awareness among Students - A Teenager's Perspective
}

\author{
Archisha Bansal \\ Class $12^{\text {th }}$ student, Delhi Public School, R. K. Puram, New - Delhi, India \\ Corresponding author Email id: r21160archisha[at]dpsrkp.net \\ Running title: Lack of awareness against epilepsy
}

\begin{abstract}
The psychosocial burden brought by epilepsy is majorly there in societies of India along with enormous financial burden forced on the individual and their family. Remedies for the condition range from 'magic powders' to sorcery and sheer denial - local norms and social practices dictate the course of action. Some of these practices are hurtful, illogical and have brought about disgrace for the afflicted individual and their family, chronic weakness and most noticeably a worsening of the illness. Epilepsy is on the rise worldwide and sadly, most secondary school students have deficient recognition, information and hold negative convictions about the illness. It is vital to comprehend this information for effective control, prevention and treatment of epilepsy in resource poor settings like India. With this in mind, this investigation was planned to evaluate the degree of awareness in the students of Delhi - NCR (National Capital Region).
\end{abstract}

Keywords: seizures, convulsions, myths and facts, neurological disorder, knowledge among students

\section{Introduction}

Epilepsy is a complex neurological condition, which remains one among the foremost misconstrued and maligned medical ailments. Even during the modern times, when science has advanced so much, there are over 50 million epilepsy patients worldwide; $80 \%$ of which belong to low and middle income countries like India.1 Epileptic patients are the victims of prejudice and bias, not only within the rustic rural societies but also among the apparently progressed and enlightened urban populace.

Epilepsy is defined by International League against Epilepsy (ILAE; 1993) as a condition characterized by recurrent epileptic seizures, unprovoked by any immediate identified cause. 2

The aetiology of this disease is multifactorial and practically any insult to the brain might bring about seizures. It may result from infections, infestations, brain damage from prenatal or perinatal causes (for example loss of oxygen or trauma during birth, low birth weight), stroke that restricts the quantity of oxygen to the brain, genetic/ metabolic causes, severe head injury and brain tumours. 3

In underdeveloped and developing countries, epilepsy has been commonly associated with high rates of brain infections like tuberculosis, neurocysticercosis (caused by parasite Taenia solium) because of dirty hands, contaminated food, poor sanitation and hygiene practices, which are due to poor socio - economic conditions. Antenatal causes like maternal malnourishment and unsatisfactory care are also greatly responsible for paediatric epilepsy. 1

Social demoralization, when the lay public are witness to an epileptic episode, is more troublesome for the patient than the disease itself and it impacts youngsters the most as they face parental, school and peer pressure to hide their illness. This social segregation and negative, generalized convictions result in loss of identity and lower self worth.

Moreover, the degree of knowledge determines the quality of life and helps in minimizing the fallacies and superstitions.

Keeping this in mind, this survey was planned and arranged among the senior secondary school students to identify their level of information, beliefs and mindfulness towards recognition, care and management of epilepsy.

\section{Materials and Methods}

An investigation was planned in January 2021 among the senior secondary school students of Delhi - NCR (National capital area). A written questionnaire (Table 1) was prepared in English and Hindi (local language). The inquiries were either different decision questions (multiple choice questions where more than one option can be chosen) or binary (yes/no). It was structured about different parts of the ailment including causative elements, impacts, doubts, mindfulness and emergency treatment practices. Informed consent was taken. Collected information was entered in Microsoft Excel and was examined utilizing the statistical tools of means, frequencies and percentages. 


\section{International Journal of Science and Research (IJSR) \\ ISSN: 2319-7064 \\ SJIF (2020): 7.803}

Table 1: Questionnaire for assessing knowledge related to epilepsy

\begin{tabular}{|c|c|c|c|}
\hline \multirow{5}{*}{$\begin{array}{l}\text { Questions for } \\
\text { assessing } \\
\text { awareness }\end{array}$} & 1. & Have you ever heard of Epilepsy? & Yes / No \\
\hline & 2. & Have you ever observed an epileptic fit? & Yes / No \\
\hline & 3. & Do you have a relative/ known who suffers/ suffered from epilepsy? & Yes / No \\
\hline & 4. & Do you think Epilepsy is a form of insanity? & Yes / No \\
\hline & 5. & $\begin{array}{l}\text { Do you know about any warning signs of Epilepsy like cerebral pain, mental aggravation, and } \\
\text { stomach uneasiness? }\end{array}$ & Yes / No \\
\hline \multirow[t]{2}{*}{$\begin{array}{l}\text { For assessing } \\
\text { causative } \\
\text { factors }\end{array}$} & 6. & $\begin{array}{l}\text { What do you think causes Epilepsy? } \\
\text { a) Infection } \\
\text { b) Mental illness } \\
\text { c) Accident/ Head Trauma } \\
\text { d) Will of God } \\
\text { e) Evil spirits, supernatural powers } \\
\text { f) Spiritual possession } \\
\text { g) Broken taboos } \\
\text { h) Past sins } \\
\text { i) Genetics/ hereditary/ family history } \\
\text { j) Alcohol } \\
\text { k) Brain disease } \\
\text { l) Neurological disorder }\end{array}$ & \\
\hline & 7. & $\begin{array}{l}\text { Can factors like stopping anti epileptic medication, staying hungry and not having enough rest } \\
\text { trigger seizures? }\end{array}$ & Yes / No \\
\hline \multirow{9}{*}{$\begin{array}{l}\text { Beliefs and } \\
\text { effects }\end{array}$} & 8. & If you had the opportunity, would you employ someone with epilepsy? & Yes / No \\
\hline & 9. & Would you be willing to work with someone with Epilepsy? & Yes / No \\
\hline & 10. & Do you think Epilepsy is an obstacle in education? & Yes / No \\
\hline & 11. & Would you play/ allow your child to play with a child with Epilepsy? & Yes / No \\
\hline & 12. & Would you marry/ allow anyone to marry someone with Epilepsy? & Yes / No \\
\hline & 13. & $\begin{array}{l}\text { Would you and/ or your family hide the fact that you/ your family member have/ has Epilepsy from } \\
\text { the outside world? }\end{array}$ & Yes / No \\
\hline & 14. & Do you think Epilepsy affects intelligence? & Yes / No \\
\hline & 15. & Do some Epileptic patients bite their tongues during a seizure? & Yes / No \\
\hline & 16. & Do you think Epilepsy is contagious/ infectious? & Yes / No \\
\hline \multirow[t]{4}{*}{ Treatment } & 17. & Can Epilepsy be cured? & Yes / No \\
\hline & 18. & $\begin{array}{l}\text { Who can treat it? } \\
\text { a) Neurologist/ Neurosurgeon/ Allopathic doctors } \\
\text { b) Faith healers/ religious healers } \\
\text { c) Ayurvedic doctors }\end{array}$ & \\
\hline & 19. & $\begin{array}{l}\text { If someone is having an Epileptic seizure in front of you, what will be your course of action? } \\
\text { a) Make him/ her smell leather slippers, shoes, belts } \\
\text { b) Force something like a spoon, fingers or gag into his/ her mouth } \\
\text { c) Give him/her something to hold } \\
\text { d) Restrain him/ her } \\
\text { e) Burn his/ her skin with a hot iron rod } \\
\text { f) Scour his/her hands } \\
\text { g) Toss water } \\
\text { h) Pour urine of animals } \\
\text { i) Call a faith/ religious healer for help } \\
\text { j) Call a doctor for help }\end{array}$ & \\
\hline & 20. & $\begin{array}{l}\text { Do you think that correct first aid is, stay - safe - side? } \\
\text { 1) Stay with the person and start timing the seizure } \\
\text { 2) Keep the person safe } \\
\text { 3) Turn the person onto their side if they are not awake and aware } \\
\text { 4) Do not put anything in their mouth } \\
\text { 5) Do not restrain } \\
\text { 6) Call the doctor/ ask for medical help }\end{array}$ & Yes / No \\
\hline
\end{tabular}

\section{Results}

An absolute count of 478 finished the survey. There were $51 \%$ Females and $49 \%$ Males. Every participant was in the age group of 15 years -18 years. $90 \%$ of the students had not seen an epileptic patient previously.

The gathered information was separated into 3 headings: applied information about epilepsy, mentality towards epileptic patient and the management of epilepsy.
1) Applied information about epilepsy

The majority of the participants wrongly accepted that epilepsy is a psychological problem and only $10 \%$ of students believed epilepsy to be an actual neurological issue. There were misconceptions prevalent about the reasons for epilepsy, like 'after effect of evil eyes' $(60 \%)$ and 'past sins' $(30 \%)$.

\section{2) Demeanour towards epileptic patients}

$90 \%$ of students accepted that epilepsy is an obstacle to education and training while $80 \%$ felt that it meddles with business and marriage. $10 \%$ of the students, who had seen an

\section{Volume 10 Issue 9, September 2021} www.ijsr.net 
epileptic episode before, felt dread on seeing an epileptic patient which was followed by a feeling of stress and pity while only $6 \%$ of them were able to offer assistance. Majority of the students would not protest sitting nearby an epileptic kid in the study hall or playing with him/her. Almost all of the students believed that this illness is not contagious.

\section{3) The management of epilepsy}

$83 \%$ of them said scouring hands, tossing water, smelling shoes or socks are the principle medical aid solutions to treat epilepsy. $50 \%$ of them would give the patient a metal item to hold and $40 \%$ would place fingers into the patient's mouth. Just under half of the students knew about factors that could trigger seizures like stopping anti - epileptic drugs, hardships of rest, staying hungry. Only $33 \%$ of the students knew about warning signs like cerebral pain, mental aggravation, and stomach uneasiness. $75 \%$ of the participants thought that medications can diminish the recurrence of seizures however are not the complete cure, thus religious help along with modern medicine is beneficial.10\% of the students would strictly urge medical assistance as the sole treatment option. Just $7 \%$ would accurately permit the seizure to run its own course and knew about the correct first aid, that is, stay safe - side.

- Stay with the person and start timing the seizure

- Keep the person Safe

- Turn the person onto their Side if they are not awake and aware

- Do not put anything in their mouth

- Do not restrain

- Call the doctor/ ask for medical help

\section{Discussion}

Epilepsy is a disease of the brain characterized by recurrent seizures, which are brief episodes of involuntary movement that may involve a part of the body (partial) or the entire body (generalized). This study was planned to gauge the knowledge and awareness associated with the disease.

This survey clearly indicates that despite a lot of advancement in the clinical medical field, education and different methodologies embraced by the WHO and various NGOs, the discernment, shame and victimization against epileptic patients continue.

Truly, epilepsy was once viewed as a sacred sickness of God, invocation of the deity. Some thought it was because of possession by evil spirits or breaking certain taboos. 4 Region specific traditions, customs and non - secular beliefs and convictions that are deep rooted in our society can be attributed as the foremost reasons for the fearful and negative attitude, harmful prejudice and ill disposition towards the illness and the ill. Traditionally, the outlook of customary Indian families is such that they frequently visit folk practitioners, faith healers, religious healers and witchcrafts doctors.5 Due to this, legitimate diagnosis and treatment is further postponed. The fantasies about epilepsy are numerous and the majority of them actually endure (Table 2).6
Table 2: Common myths associated with epilepsy.

\begin{tabular}{|c|c|}
\hline Myths & Facts \\
\hline $\begin{array}{c}\text { Epilepsy is a direct result of } \\
\text { ownership by insidious spirits or } \\
\text { breaking certain restrictions. }\end{array}$ & $\begin{array}{c}\text { Epilepsy is a neurological } \\
\text { disorder. }\end{array}$ \\
\hline $\begin{array}{c}\text { Use of leather slippers, onion, } \\
\text { iron bar or key and burning the } \\
\text { skin with a hot needle or iron } \\
\text { rod during an acute attack will } \\
\text { stop the attack. }\end{array}$ & $\begin{array}{c}\text { These things won't stop the fits; } \\
\text { rather will injure the epileptic } \\
\text { patients. }\end{array}$ \\
\hline $\begin{array}{c}\text { Treatment by quacks, confidence } \\
\text { healers will cure and fix the fits. }\end{array}$ & $\begin{array}{c}\text { A neurologist, neurosurgeon or } \\
\text { epileptic surgeon should treat it. }\end{array}$ \\
\hline $\begin{array}{c}\text { Never touch the patients with a } \\
\text { fit. The issue goes to be passed } \\
\text { to you. }\end{array}$ & $\begin{array}{c}\text { Touching the patients cannot } \\
\text { pass on epilepsy. }\end{array}$ \\
\hline $\begin{array}{c}\text { Epilepsy to our dearest carries } \\
\text { disgrace to the family, so it's } \\
\text { smarter to cover it. }\end{array}$ & $\begin{array}{c}\text { Like any other disease, epilepsy } \\
\text { is treatable. Its better to seek } \\
\text { proper treatment instead of } \\
\text { hiding it. }\end{array}$ \\
\hline $\begin{array}{c}\text { Epilepsy could also be a sort of } \\
\text { franticness and it should be } \\
\text { treated in a psychiatric asylum. }\end{array}$ & $\begin{array}{c}\text { Epilepsy is a disorder of brain } \\
\text { function. So neurologists, } \\
\text { physicians, should treat it. }\end{array}$ \\
\hline
\end{tabular}

Traditionally, the treatment for this disease is making the patient smell calfskin things like shoes, belts, and soiled socks. Many folks correctly suggest that epileptic patients should avoid going near fire, deep water, and altitude. Practising black magic, wearing talismans and applying heavenly debris are techniques taken on by certain individuals. Often utilized fixes included fasting, penances and expulsions (driving out devils). 7

Students generally lacked knowledge about the warning signs of epilepsy, which is significant in order to enable timely and correct assistance and management.

It has been shown within literature that an exceptionally less percentage of people visit neurologists or neurosurgeons for this disease. 1 Also, the poor economic background, high price of anti - epileptic medications and travel distance from the hospital determine the right consultation with the concerned doctors. It has been seen that the patients are more inclined towards herbal medicines, which is again an obstacle in correct treatment. Also, there's a shortage of trained professionals. 8 There is a treatment gap, which suggests people are not able to access or are not accessing healthcare services and biomedical facilities for diagnosis and treatment. Some people do not stick to appropriate medical therapy and prescribed anti - epileptic medications.9

A developing child is the most influenced by this discrimination. The disease itself is not much of a problem; rather this negative stereotype that society has created is more devastating. Children with epilepsy are forced to drop out of their schools. It is a major hindrance in marriages, relationships and employment opportunities.

Traditionally, these patients are not given employment as people are of the opinion that it will pass on through physical contact and would carry and bring negative energy and fiendish spirits to the house or workplace. People don't permit their children to mingle and play with epileptic children for the same reason that results in brutal social casting - out of these children. But, fortunately this survey clearly indicates the change in perception about 
communicability of this disease because the students show no apprehension in sitting and playing with epileptic patients.

So, the necessity of the hour is spread of information about the correct evidence and reasons associated with the disease, through thorough educational and instructive camps, motion pictures, television, social networking sites and sources from the Internet, which are the most important sources of data in the present scenario.

Also, we need to educate and instruct the parents, the guardians, the elderly and teachers, as these are the ones who pass their insight, knowledge and beliefs to young children. We want to change our present education framework by teaching health education, and only then we can change the perception of young minds against epilepsy.

\section{Conclusion}

This study shows that students have below average knowledge about the disease. India is such a hugely populated country that it needs better education, better sanitation and hygiene practices, and not to forget a better doctor - population ratio. It is suggested that the correct knowledge about aspects of disease and its first aid management should be there in the school curriculum. Through education, we can change the view of the youth against epilepsy. Only then, we can live in a healthy society.

\section{Conflict of interest: NIL}

\section{References}

[1] Panagariya A, Sharma B, Dubey P, Satija V, Rathore M. Prevalence, Demographic Profile, and Psychological Aspects of Epilepsy in North - Western India: A Community - Based Observational Study. Ann Neurosci.2018 Dec; 25 (4): 177 - 86. doi: 10.1159/000487072.

[2] Santhosh NS, Sinha S, Satishchandra P. Epilepsy: Indian perspective. Ann Indian Acad Neurol.2014 Mar; 17 (Suppl 1): S3 - S11. doi: 10.4103/0972 2327.128643.

[3] Chaitra KM, Agrawal A, Varshini P, Anil H, Athani S. Public awareness towards first aid management of epilepsy. Int J Contemp Pediatr 2019; 6: 2189 - 92.

[4] Bhattacharya S, Singh A. Beliefs of a traditional rural Indian family towards naturalistic and faith healing for treating epilepsy: a case study. BMJ Case Rep.2018 Jun 17; 2018: bcr2018225405. doi: 10.1136/bcr - 2018 225405.

[5] Choi - Kwon S, Kim EK, Youn SM, Choi JM, Lee SK, Chung CK. Common misconceptions in people with epilepsy. J Clin Neurol.2006 Sep; 2 (3): 186 - 93. doi: 10.3988/jcn.2006.2.3.186.

[6] Singh S, Mishra VN, Rai A, Singh R, Chaurasia RN. Myths and Superstition about Epilepsy: A Study from North India. J Neurosci Rural Pract.2018; 9 (3): 359 362. doi: 10.4103/jnrp. jnrp_63_18

[7] Thapa L, Bhandari TR, Shrestha S, Poudel RS. Knowledge, Beliefs, and Practices on Epilepsy among High School Students of Central Nepal. Epilepsy Res
Treat.2017; 2017:

6705807.

doi: 10.1155/2017/6705807.

[8] Goel S, Singh N, Lal V, Singh A. Knowledge, attitude and practices of students about first aid epilepsy seizures management in a Northern Indian City. Ann Indian Acad Neurol 2013; 16: 538 - 43.

[9] Garg D. Specific considerations for epilepsy in India. Curr Med Issues 2020; 18: 105 - 10. doi: 10.4103/cmi. cmi_6_20.

Volume 10 Issue 9, September 2021

www.ijsr.net

Licensed Under Creative Commons Attribution CC BY 